\title{
AKSELERASI INDUSTRIALISASI PERDESAAN INOVATIF DAN KELEMBAGAAN PERTANIAN MEWUJUDKAN KESEJAHTERAAN PETANI
}

\author{
ACCELERATE INNOVATIVE RURAL INDUSTRIALIZATION AND \\ AGRICULTURAL INSTITUTIONS CREATE THE WELFARE OF FARMERS
}

\author{
Roosganda Elizabeth*1, Giovanni Inez EM², Geraldy Samuel Ivan ${ }^{2}$ \\ ${ }^{1}$ PSEKP-Kementan \\ ${ }^{2}$ Manajemen Industri; Manajemen Agribisnis, IPB \\ Email: roosimanru@yahoo.com \\ (Diterima 04-07-2021; Disetujui 22-07-2021)
}

\begin{abstract}
ABSTRAK
Masih relatif lemahnya dayasaing produk olahan berbasis pertanian, penyebab Indonesia dikenal pengimpor pangan pabrikan, karena masih sebagai pengekspor raw material berbasis pertanian. Keunggulan komparatif produk primer hanya mengandalkan kelimpahan SDA dan TK tak terdidik sehingga masih didominasi produk mentah. Di era globalisasi perdagangan bebas menuntut produk olahan berdayasaing tinggi, untuk mampu memenuhi tingginya syarat kualitas dan persaingan pasar global. Dengan metode deskriptif kualitatif, tulisan ini bertujuan mengemukakan secara komprehensif pentingnya peningkatan produk pangan olahan yang berkualitas dan berdayasaing, didukung pengembangan kelembagaan terkait produk olahan. Program pengembangan teknologi dan investasi melalui pengembangan dan peningkatan kinerja industri pengolahan berbasis pertanian di pedesaan diprediksi mampu menjadi "mesin penggerak" kemajuan ekonomi yang tangguh. Sebagai solusi efisiensi, efektifitas, kontiniutas dan kesinambungan proses pengadaan bahan baku, tenaga kerja dan pembiayaan (permodalan) produk olahan, bila industri pengolah berada di sekitar bahan baku diproduksi (pertanian di perdesaan). Pengembangan peran industrialisasi untuk peningkatan nilai tambah produk termasuk mengalihkan produk pertanian primer (raw material) menjadi produk olahan sebagai upaya mengurangi impor. Peran kelembagaan berfungsi sejalan program pembangunan yang dilaksanakan mampu memotori industrialisasi perdesaan, menciptakan lapangan kerja dan peningkatan pendapatan di perdesaan.
\end{abstract}

Kata Kunci: dayasaing, industrialisasi, teknologi inovatif, kelembagaan pertanian perdesaan

\begin{abstract}
The relatively weak competitiveness of agricultural-based processed products is the reason why Indonesia is known as an importer of manufactured food, because it is still an exporter of agricultural-based raw materials. The comparative advantage of primary products only relies on the abundance of natural resources and uneducated TK so that they are still dominated by raw products. In the era of globalization, free trade demands highly competitive processed products, to be able to meet the high quality requirements and global market competition. Using a qualitative descriptive method, this paper aims to comprehensively describe the importance of increasing quality and competitive processed food products, supported by institutional development related to processed products. The technology development program and investment through the development and improvement of the performance of the agricultural-based processing industry in rural areas is predicted to be able to become the "engine" of strong economic progress. As a solution for efficiency, effectiveness, continuity and continuity of the process of procuring raw materials, labor and financing (capital) for processed products, if the processing industry is around the raw materials produced (agriculture in rural areas). Development of the role of industrialization to increase the added value of products, including diverting primary agricultural products (raw materials) into processed products as an effort to reduce imports. The role of the institution
\end{abstract}


functions in line with the development programs implemented to be able to drive rural industrialization, create jobs and increase income in rural areas.

Keywords: competitiveness, industrialization, innovative technology, rural agricultural institutions

\section{PENDAHULUAN}

Tehnik pengolahan industri di Indonesia masih didominasi cara-cara tradisional yang terkesan menjadi tertinggal dan terdesak oleh produk olahan modern (Balitbangtan. 2015; Elizabeth. 2018a). Di era globalisasi sekarang ini, produk perdagangan seluruh negara menghadapi dinamika lingkungan strategik internasional, yang menuntut hasil produk pertanian yang berdayasaing, memenuhi tingginya persyaratan kualitas, disertai ketatnya persaingan di pasar global. Sementara itu, daya saing produk olahan komoditi pertanian Indonesia masih lemah, karena selama ini hanya mengandalkan keunggulan komparatif dengan kelimpahan sumberdaya alam dan tenaga kerja tak terdidik, sehingga produk yang dihasilkan masih didominasi oleh produk primer atau bersifat natural. Tidak dipungkiri membanjirnya produk luar negeri yang, harusnya diartikan sebagai tantangan dan peluang yang harus dihadapi dengan meningkatkan daya saing produk domestik melalui perbaikan kualitas, kuantitas dan efisiensi produk.

$\begin{array}{lcr}\text { Sebagai } & \text { sumber } & \text { kekuatan } \\ \text { pengembangan } & \text { pengolahan } & \text { produk } \\ \text { perdagangan } & \text { Indonesia } & \text { yang }\end{array}$
berdayasaing, keragaman teknologi pengolahan produk pertanian yang inovatif di setiap daerah harus dapat didayagunakan sesuai kondisi global. Dibutuhkan industri pengolah di sekitar bahan baku (pertanian di perdesaan) sebagai solusi efisiensi, efektifitas, kontiniutas dan kesinambungan proses pengadaan bahan baku, tenaga kerja dan pembiayaan (permodalan) produk olahan; serta berbagai fungsi kelembagaan pertanian di perdesaan, yang dipasarkan melalui perbaikan sistem produksi, pasca panen dan pengolahan. Dengan metode deskriptif kualitatif, tulisan ini bertujuan mengemukakan secara komprehensif pentingnya peningkatan produk pangan olahan yang berkualitas dan berdayasaing, didukung pengembangan kelembagaan terkait produk olahan. Program pengembangan teknologi dan investasi melalui pengembangan dan peningkatan kinerja industri pengolahan berbasis pertanian di pedesaan diprediksi mampu menjadi "mesin penggerak" kemajuan ekonomi yang tangguh. 
Berbagai permasalahan timbul berkaitan dengan kebelummampuan industri pengolahan domestik terkait upaya pengembangan industri pertanian dalam menghasilkan produk olahan yang berkualitas dan berdayasaing, keragaman dan tingkat permintaan pasar, disertai oleh kelengkapan regulasi dan peraturan yang berpihak pada petani produsen bahan baku.

\section{METODE PENELITIAN}

Secara umum dalam penulisannya berbagai data dan informasi yang telah terkumpul akan dipilah dan dibahas sesuai tujuan penulisan dengan metode deskriptif kualitatif berbagai hasil analisis data sekunder dan data primer yang diperoleh dari lapang, yang dilakukan dengan mengidentifikasi, me-review dan menganalisis berbagai implementasi program, mengevaluasi kesesuasian dan ketepatan program dan implementasinya di lapang. Untuk memperluas dan memperkaya cakupan pembahasan, dilakukan review berbagai kajian yang telah dilakukan sebelumnya dan tulisan terkait lainnya.

\section{HASIL DAN PEMBAHASAN}

Indonesia merupakan negara pengekspor dan sekaligus pengimpor produk pertanian, karena sampai saat ini sebagian besar ekspor berupa bahan mentah (raw material) dan mengimpor kembali setelah berbentuk produk olahan, baik pada komoditi pangan, hortikultura, perkebunan maupun peternakan (Rachmat et al, 2012 dalam: Elizabeth, 2019). Dapat diartikan bahwa Indonesia dirugikan karena nilai tambah produk tersebut telah diambil alih oleh negara pengolahnya. Berdasarkan prinsip liberalisasi, globalisasi perdagangan bertujuan mengeliminasi hambatan perdagangan (barriers to trade) melalui keterbukaan pasar dan harmonisasi dengan penyeragaman standar mutu dan keamanan produk. Daya saing produk olahan komoditi pertanian Indonesia masih lemah, karena selama ini hanya mengandalkan keunggulan komparatif dengan kelimpahan sumberdaya alam dan tenaga kerja tak terdidik (factor-driven), sehingga produk yang dihasilkan didominasi oleh produk primer atau bersifat natural resources-based dan unskilled-labor intensive (Elizabeth. 2017; 2017a; 2018). Era globalisasi merupakan masa terbuka luasnya peluang pasar bagi produk-produk perdagangan seluruh negara, termasuk produk pertanian olahan yang disertai ketatnya persaingan, tinggi dan ketatnya 
persyaratan kualitas produk yang dipasarkan.

Pembangunan pertanian di era globalisasi sekarang ini, dihadapkan kepada dinamika lingkungan strategik domestik dan internasional, yang menuntut hasil produk pertanian yang memiliki kemampuan dan berdayasaing di pasar global. Dalam perencanaan dan pelaksanaan pembangunan perdesaan, perhatian hendaknya ditekankan pada perbaikan dan pembenahan ragam kelembagaan yang berdayaguna dan berhasilguna serta ke arah peningkatan pendapatan, kesempatan kerja dan berusaha di perdesaan. Sebagai penghela pembangunan pertanian, industri pengolahan diharapkan mampu menciptakan berbagai produk pertanian dan produk olahannya, mampu memotori industrialisasi perdesaan, serta mampu menciptakan lapangan kerja dan pendapatan di perdesaan. Pengembangan peran industrialisasi untuk peningkatan nilai tambah produk termasuk mengalihkan produk pertanian primer (raw material) menjadi produk olahan sebagai upaya mengurangi impor. Pengembangan industri pengolahan berbasis pertanian di perdesaan dalam menghasilkan produk olahan yang berkualitas dan berdayasaing, mendukung pengembangan fungsi dan peran kelembagaan, serta pemasaran produk pangan olahan.

Pembangunan pertanian Indonesia harus mengantisipasi pengembangan produk olahan ke arah industrialisasi sehingga ekspor produk pertanian secara bertahap dapat beralih dari produk primer (bahan baku) ke produk olahan (Balitbangtan. 2015; Kemenkeu Ekuin. 2016; Elizabeth. 2019). Termasuk upaya mengurangi impor produk olahan, dimana ekspor secara bertahap beralih dari produk pertanian primer (bahan baku) ke produk olahan. Dengan perbaikan dan pengembangan teknologi pengolahan, pengembangan kelembagaan ketenagakerjaan dalam bentuk pembinaan dan pelatihan untuk meningkatkan pengetahuan dan keterampilan SDM dalam pembuatan produk olahan, dan pengembangan kelembagaan pemasaran produk pertanian olahan sangat dibutuhkan demi pengembangan industri pertanian di perdesaan (Balitbangtan. 2015; Kemenkeu; 2015; Kemenkeu Ekuin. 2016). Peran kelembagaan berfungsi sejalan program pembangunan yang dilaksanakan mampu memotori industrialisasi perdesaan, menciptakan lapangan kerja dan peningkatan 
pendapatan di perdesaan (Elizabeth. 2018; 2018a).

\section{Pengembangan Usaha Industri Produk Olahan Indonesia}

Daya saing dan nilai tambah produk pertanian umumnya berasal dari produk olahan, sehingga pengembangan dan peningkatan produk olahan menjadi tujuan strategis dalam pencapaian sasaran membangun pertanian, mengembangkan perekonomian dan memberdayakan masyarakat perdesaan. Beberapa kriteria diperlukan dalam pengembangan industri pengolahan, diantaranya (Rachmat. et al, 2012): berbasis kepada potensi sumberdaya lokal; memiliki peluang pasar ekspor dan domestik yang tinggi; mendukung ketahanan pangan nasional; menghasilkan nilai tambah yang tinggi; didukung oleh kemampuan IPTEK dan SDM untuk menghasilkan produk yang berdaya saing; memperhatikan kelestarian lingkungan dengan cara menggunakan teknologi bersih; menerapkan prinsip kemitraan yang berwawasan bisnis; layak secara administratif dan ekonmis untuk dikembangkan.

Pada sub sektor tanaman pangan dan peternakan terjadi defisit nilai perdagangan pada produk segar dan produk olahan, sementara pada sub sektor hortikultura, defisit nilai perdagangan disebabkan terjadinya defisit perdagangan produk segar lebih besar dari surplus nilai perdagangan produk olahan. Secara umum nilai perdagangan pertanian Indonesia berada pada posisi surplus, kontribusi suplus perdagangan tersebut terutama berasal dari sub sektor perkebunan, baik untuk produk segar maupun olahan. Sebagai gambaran surplus produk segar AS\$ 9,165 juta dan surplus produk olahan AS\$ 3,975 juta, berasal dari suplus perdagangan produk pertanian sebesar AS\$ 13,140 juta. Surplus perdagangan produk perkebunan sebesar AS\$ 17,632 juta, terdiri atas suplus produk segar AS\$12,742 juta dan surplus produk olahan AS\$ 4,891 juta. Sementara nilai perdagangan sub sektor lainnya cenderung defisit.

Tabel. Neraca Produk Segar dan Produk Olahan Pertanian ( US \$ juta)

\begin{tabular}{lcccccccc}
\hline \multirow{2}{*}{ Sub Sektor } & \multicolumn{3}{c}{ Ekspor } & \multicolumn{3}{c}{ Impor } & \multicolumn{2}{c}{ Neraca Perdagangan } \\
\cline { 2 - 8 } & Segar & Olahan & Segar & Olahan & Segar & Olahan & Total \\
\hline Tanaman pangan & 54 & 267 & 2.236 & 502 & -2.182 & -235 & -2.417 \\
Hortikultura & 66 & 314 & 848 & 230 & -782 & 84 & -698 \\
Perkebunan & 13.992 & 7.59 & 1.25 & 2.699 & 12.742 & 4.891 & 17.632 \\
Peternakan & 155 & 599 & 769 & 1.364 & -613 & -765 & -1.378 \\
$\quad$ Total & $\mathbf{1 4 . 2 6 7}$ & $\mathbf{8 . 7 7}$ & $\mathbf{5 . 1 0 2}$ & $\mathbf{4 . 7 9 5}$ & $\mathbf{9 . 1 6 5}$ & $\mathbf{3 . 9 7 5}$ & $\mathbf{1 3 . 1 4}$ \\
\hline Sumber: Data sekunder, diolah (2018) & & & & & &
\end{tabular}


Pembangunan dan pengembangan industri pengolahan di perdesaan, dapat diprediksi sebagai salah satu solusi efisiensi, efektifitas, kontiniutas dan kesinambungan proses dan pengadaan bahan baku, tenaga kerja dan pembiayaan (permodalan) produk olahan, karena industri pengolah berada di sekitar bahan baku diproduksi (pertanian di perdesaan) (Elizabeth. 2018a). Berkembangnya kegiatan pengolahan terutama ditentukan oleh dinamika permintaan dan penawaran produk tersebut, serta sangat bergantung dan sangat dipengaruhi berperan dan berdayagunanya kelembagaan pemasaran suatu produk. Indonesia merupakan negara yang memiliki komoditi pertanian, perkebunan, dan peternakan sebagai kekayaan SDA, tinggal bagaimana kemampuan SDM untuk mengolah dan mengelolanya menjadi produk-produk yang bernilai dan berdayasaing tinggi, serta kemampuan kelembagaan pemasaran produk-produk tersebut (Elizabeth. 2018). Prospek produk yang berorientasi ekspor, sangat tergantung kepada pasar internasional, yang menyangkut sisi permintaan dari negara konsumen dan sisi penawaran dari negara produsen pesaing, dimana resultante persaingannya tercermin pada perkembangan dan tingkat harga (acuan efisiensi alokasi sumberdaya/salah satu faktor produksi), dan termasuk kebijakan negara terkait, meskipun penerapan kebijakan proteksi negara maju yang merugikan negara berkembang cenderung semakin terbuka akibat desakan penerapan sistem perdagangan bebas.

Pengembangan produk olahan merupakan produk yang diproduksi: sepenuhnya untuk konsumsi domestik, untuk substitusi impor, dan untuk promosi ekspor. Keseluruhan aspek tersebut sangat dipengaruhi oleh dinamika penawaran dan permintaan, serta peran aktif lembaga pemasaran. Pada kondisi tersebut, dasar kekuatan daya saing di pasar internasional adalah tingkat keunggulan kompetitif (diukur oleh kelayakan secara finansial/menguntungkan bagi pengusaha), yang lebih mudah dibangun bila didukung oleh keunggulan komparatif (yang bisa saja tidak terjadi bila ada hambatan bersifat disinsentif seperti prosedur berbelit/sulit, pajak, dan ekonomi biaya tinggi lainnya). Permintaan dan perubahan penawaran suatu produk konsumsi sangat terkait dengan biaya produksi, sehingga pada kondisi perdagangan global yang terbuka akan masuk produk pengganti (substitusi) dari luar, yang sangat dipengaruhi oleh 
jumlah kebutuhan domestik dan daya saing produk domestik. Pengembangan industri pengolahan dipengaruhi ketersediaan bahan baku (kecukupan volume, kualitas dan kontiniuitas); minat pelaku usaha; dukungan ketersediaan infrastruktur penunjang (kondisi jalan, ketersediaan listrik, air bersih, sarana telekomunikasi dan lain-lain) (Kusumawardani, 2012; Kaniasari, 2012; Kemenkeu, 2014. Kemen Ekuin, 2016; Marimin, 2011). Cara pengolahan produk olahan bermutu dan layak masuk pasar internasional harus mengikuti acuan sistem mutu yang ditetapkan yaitu Pedoman Pengolahan yang Baik (Good Manufacturing Practices/GMP), yang mencakup faktor-faktor: lokasi, bangunan, ruang dan sarana, proses dan peralatan pengolahan, penyimpanan dan distribusi produk olahan, kebersihan dan kesehatan pekerja, serta penanganan limbah dan pengolahan lingkungan.

\section{Prospek Pengembangan Produk Olahan Industri Berbasis Pertanian Indonesia}

Produk pertanian olahan asal tumbuhan adalah mengubah bahan baku menjadi produk primer, setengah jadi atau produk jadi (Permentan No 35/Permentan/OT.140/7/2008), yang bertujuan untuk meningkatkan daya simpan ataupun meningkatkan nilai tambah hasil pertanian asal tumbuhan. Kegiatan pengolahan tersebut dilakukan pada komoditi di bidang tanaman pangan, hortikultura, perkebunan dan peternakan. Tahap pengolahan dan pengawetan meliputi kegiatan: pengolahan bahan, pemanasan, fermentasi, pengeringan, pendinginan, pengemasan, pengalengan, dan lainnya; dimana untuk menghasilkan suatu produk olahan dilakukan melalui satu atau lebih proses/kegiatan tersebut. Berbagai industri pangan skala besar, sedang dan kecil menunjukkan bahwa produk ubi kayu (singkong) berupa tepung cassava (tapioka) digunakan dalam pembuatan produk-produk mie (baik mie instan atau mie basah), kerupuk, tepung bumbu (coating mix), snack food (makanan ringan), produkproduk daging olahan (meat product), sereal, minuman, bumbu masak instan, hingga bubur bayi instan, komponen bahan baku jamu, kosmetik, serta komponen bahan baku pakan ternak. Disamping itu, turunan produk olahan dari ubikayu adalah glukosa, fruktosa, maltodekstrin dan sebagainya.

Komoditi hortikultura (sayuran dan buah), umumnya dikonsumsi dalam bentuk segar. Produk olahan sayuran yang umum dilakukan adalah yang diawetkan, dikeringkan, dibekukan, 
sayuran mix olahan, serta sebagai komponen bahan baku obat-obatan, jamu dan kosmetik. Di samping itu, beberapa komoditi sayuran juga dibuat dalam bentuk jus, pasta (cabe), tepung, bumbu, dan minyak (lobak dan lain-lain). Konsumsi buah terbesar adalah dalam bentuk segar. Produk buah matang olahan dapat berupa produk yang dikalengkan (diawetkan, fruit dan mix fruits), sale (pisang, sirsak, pepaya, nanas), minuman (anggur), dan sebagai puree merupakan bahan dasar untuk pembuatan jus, jeli, sirop, selai dan produk makanan dari buah. Dari buah yang belum matang dapat dibuat produk olahan seperti: keripik, asinan, manisan dan tepung buah. Dari buah dan kulit buah juga dapat dibuat pektin (bahan untuk industri farmasi dan makanan), pupuk dan makanan ternak, dan berbagai produk olahan lainnya berupa ekstract (komponen bahan baku obat-obatan, jamu dan kosmetik).

Pengembangan produk olahan mempunyai keuntungan ganda, antara lain: sebagai promosi ekspor dan sekaligus substitusi impor; menciptakan nilai tambah pertanian; menciptakan lapangan kerja industri; dan meningkatnya adopsi teknologi (Ridwan, 2012. Faizi, 2014; Hadi, 2014;
Balitbangtan, 2015; Susilawati, 2018). Sangat bervariasinya tantangan yang dihadapi dalam globalisasi, antara lain: (i) penyediaan produk yang aman, higienis, dengan harga bersaing, yang bermutu tinggi dan berkualitas terjamin; (ii) kokohnya pasar domestik produk, supaya tidak hanya dibanjiri produk impor; (iii) kontiniutas penyediaan produk dan didukung memadainya kondisi lingkungan dan sarana. Produk olahan yang dikembangkan pada komoditi tanaman pangan, seperti: padi (beras, tepung beras), jagung, kedelai, umbi-umbian (ubi kayu, ubi jalar, talas).

Bila kondisi tersebut dapat dilakukan dengan sebaik baiknya, maka peluang pasar global dapat didayagunakan, dan diperolehnya nilai tambah, dan berarti pula akan mengurangi impor produk olahan. Hendaknya dipahami sebagai peluang untuk produk olahan Indonesia dapat bersaing di pasar global. Berbagai hasil penelitian telah mengungkapkan produkproduk pangan pertanian olahan beserta turunannya, salah satunya adalah hasil kajian), seperti yang dikemukakan berikut. Selain beras konsumsi dan berbagai variasinya, produk olahan dari beras umumnya adalah produk turunan (tepung dan pati), pangan olahan (bubur 
bayi instan, mie, krupuk, biskuit, kue basah dan kering), komponen bahan baku jamu, kosmetik, dan atau sebagai bahan baku industri (tekstil, pewarna/cat, perekat/lem), serta sekam (kulit gabah) sebagai komponen bahan baku pakan ternak (Rachmat, et al 2012; dalam: Elizabeth, 2018).

Penggunaan terbesar domestik produk kedelai adalah untuk industri tempe, tahu dan kecap, berbagai pangan olahan lainnya (tepung halus dan kasar, minyak kedelai, kerupuk, keripik, sari pati untuk susu kedele), komponen bahan baku jamu, kosmetik, serta bungkil kedelai sebagai komponen pakan ternak. Konsumsi produk jagung terbesar adalah bentuk bahan dasar bungkil jagung (komponen utama bahan baku pakan ternak). Produk olahan jagung bisa berupa tepung dan pati (maizena, bahan dasar berbagai bahan pangan olahan), menir, pati jagung, gula jagung, pati, minyak dan fraksi padat dari minyak, serta komponen bahan baku jamu, kosmetik.

Demikian halnya dengan tanaman kelapa, hampir seluruh bagiannya merupakan produk industri bernilai tinggi dan dapat dikembangkan menjadi produk turunan berteknologi tinggi. Mulai dari batang kelapa (untuk tiang/jembatan dan perabotan), serat batang dan akar pohon kelapa yang dijalin menjadi tali tambang (untuk kapal dan alat berat) yang sangat kuat, daun kelapa yang dapat dijadikan atap setelah dijalin dan dikeringkan, tempurung (batok) kelapa (perkakas/peralatan/perabotan rumahtangga dan arang), serta produk olahan lainnya dari semua bagian tanaman kelapa. Daya saing produk kelapa Indonesia terletak pada industri hilirnya, tidak lagi pada pada produk primernya. Nilai tambah dalam negeri yang potensial pada produk hilir (akhir) dapat berlipat ganda dibanding produk primernya (awal). Pengembangan industri hilir kelapa terpadu berpotensi untuk menghasilkan $\mathrm{CCO}, \mathrm{AC}, \mathrm{CF}$, dan cuka, sedangkan yang secara parsial untuk menghasilkan VCO, OC, DC, CF, BS dan CW. Hampir semua produk akhir tersebut sudah masuk pasar ekspor dan berkembang cukup baik. Permintaan pasar ekspor produk olahan kelapa umumnya menunjukkan kecenderungan yang meningkat. Produk akhir kelapa Indonesia yang sudah berkembang dengan baik adalah desiccated coconut (DC), coconut milk/cream (CM/CC), coconut charcoal (CCL), active carbon (AC), brown sugar (BS), nata de coco (ND) dan coconut fiber (CF), serta yang 
baru berkembang adalah virgin coconut oil (VCO) dan coconut wood (CW).

Hampir semua bagian tanaman tebu merupakan produk industri bernilai tinggi dan dapat dikembangkan menjadi produk turunan berteknologi tinggi. Beberapa produk derivat tebu (PDT) seperti: ethanol, ragi roti, inactive yeast, wafer pucuk tebu, papan partikel, papan serat, pulp, kertas, $\mathrm{Ca}$ sitrat dan listrik mempunyai peluang pasar yang terbuka, baik dipasar domestik maupun pasar internasional. Produk olahan kakao dapat diturunkan dari biji kakao (dibuat tepung untuk cake, minyak, dan lemak) dan kulit biji kakao. Sementara itu, produk olahan komoditi perkebunan yang berteknologi tinggi terutama berasal dari kelapa sawit, kopi, tebu dan kakao, juga termasuk tumbuhan jenis merambat (lada, panili). Diantaranya adalah CPO dan PKO yang merupakan produk olahan kelapa sawit. CPO merupakan komponen bahan baku produk olahan olein (hasilnya antara lain: minyak goreng, minyak salad, shortening, dan metil esther, yang selanjutnya biasa diturunkan menjadi produk olahan seperti biodiesel dan surfatin), asam amino, PFAD, vitamin A dan E, serta karotan. Produk olahan dari komoditi lada dan panili, selain sebagai komponen dan bahan baku obat-obatan, jamu dan kosmetik, umumnya merupakan bahan baku rempah-rempah (spicy) yang berfungsi sebagai bumbu penyedap rasa, dimana aroma dan rasanya memiliki ciri khas (brand image), dan sangat terkenal di seluruh dunia perdagangan. Demikian juga halnya dengan fungsi dan peran berbagai produk olahan dari berbagai komoditi pertanian Indonesia lainnya. Demikian halnya dengan kopi, produk olahan diantaranya: kopi instan, ekstrak kopi, dan kopi dengan kandungan kafein rendah, produk minuman lainnya, obatobatan, kosmetik, serta berbagai produk olahan lainnya yang berbahan baku kopi. Pemanfaatan produk kopi umumnya berasal dari bijinya yaitu bubuk kopi. Semua komoditi perkebunan tersebut memiliki nilai olahan yang tinggi, sehingga dibutuhkan teknologi dan SDM yang tinggi pula untuk mewujudkannya.

Produk olahan komoditi peternakan yang utama dan berorientasi ekspor adalah susu olahan (permen, es krim, dan yoghurt dengan cara pasteurisasi), daging olahan (bakso, corned beef, sosis dan abon), dan kompos (pupuk organic). Semua jenis komoditi pertanian, perkebunan dan peternakan di Indonesia memiliki fungsi dan peran strategis sebagai komponen dan bahan baku kebutuhan hidup manusia, baik sebagai 
bahan pangan (termasuk obat-obatan), sandang (termasuk kosmetik), maupun kebutuhan hidup tersier lainnya (termasuk peralatan, perkakas, dan perabotan).

\section{Peningkatan peran industry didukung pemberdayaan kelembagaan perdesaan}

Untuk menumbuhkan ekonomi perdesaan perlu upaya memperkuat jaringan sosial masyarakat dan kelembagaan, baik dari aspek struktur atau konfigurasinya (sebagai jaringan yang efisien), keanggotaan (tingkat partisipasi masyarakat), maupun peranan atau fungsi (pembagian kerja secara organik) (Elizabeth, 2014). Berbagai aspek kelembagaan pertanian di perdesaan dan pemasaran produk olahan perlu dibenahi dalam proses dan mendukung pengembangan industri pertanian dan peningkatan nilai tambah produk pertanian olahan. Industri harus mampu berperan dalam peningkatan nilai tambah (utility), penyerapan dan produktivitas kelembagaan tenaga kerja, dan memperluas jangkauan kelembagaan pemasaran melalui kajian deskriptif. Jika sistem kelembagaan dan pemasaran tidak berfungsi, maka program pengembangan teknologi maupun investasi tidak akan mampu menjadi "mesin penggerak" kemajuan ekonomi yang tangguh (Wijaya, 2011; 2013; 2014; Elizabeth, 2017; 2017a; 2018). Penguatan jaringan kelembagaan berbasis sumberdaya pertanian yang menangani teknologi pengolahan produk dengan pemberdayaan masyarakat tani merupakan salah satu faktor penting dan penunjang dalam pengembangan industri pengolahan pertanian di perdesaan.

Kelembagaan di perdesaan dapat diklasifikasikan dalam beberapa kategori (Uphoff, 1992), yaitu: administrasi lokal; pemerintah lokal; organisasi/kelembagaan beranggotakan masyarakat lokal, kerjasama usaha, pelayanan dan bisnis swasta (industri pertanian) yang dapat diintegrasikan ke dalam pasar baik lokal, regional dan global. Terdapat empat elemen kunci dalam pengembangan industri pengolahan dan kelembagaan pertanian perdesaan, yaitu: 1) aglomerasi perusahaan (cluster); 2) peningkatan nilai tambah (value added) dan mata rantai nilai (value chain); 3) jaringan pemasok dan pelanggan; dan 4) jaringan infrastruktur ekonomi fisik dan non fisik (Putra, 2014; Elizabeth, 2014; 2016; 2018; 2019). 


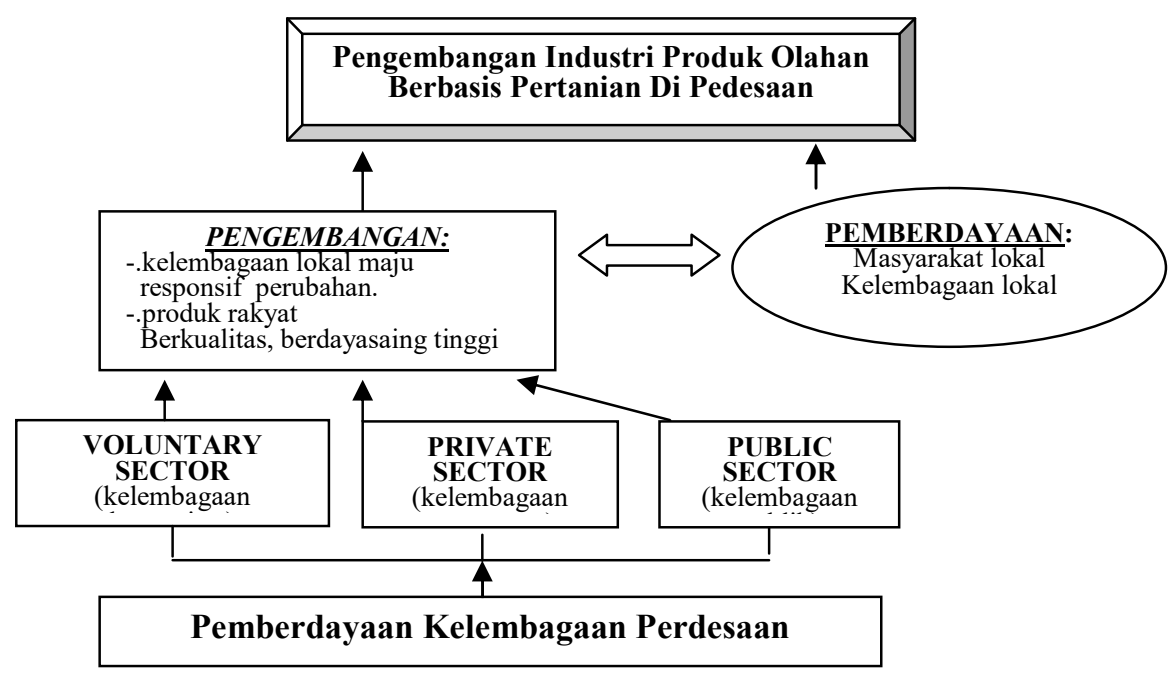

Gambar. Pemberdayaan Kelembagaan Produk Olahan Perdesaan

Pemberdayaan dan pengembangan kelembagaan di perdesaan terkait pengembangan industri pengolahan adalah dalam hal: tenaga kerja (SDM) dan pemasaran, terutama dalam implementasi teknologi inovatif pascapanen, mutlak dijadikan sebagai fokus utama dalam perancangan kebijakan pemerintah dan diperlukan untuk terwujudnya industri pengolahan berbasis produk pertanian, serta untuk memecahkan masalah ekonomi masyarakat pedesaan. Beberapa kendala dalam pengembangan industri pengolahan pertanian di perdesaan, antara lain: (i) belum berkembangnya teknologi pengolahan karena masih kecil dan terbatasnya sumber permodalan; (ii) rendahnya kualitas tenaga kerja (SDM) dan belum profesional; (iii) sarana dan prasarana belum memadai; (iv) rendahnya jaminan mutu dan kontiniutas (ketersediaan) bahan baku; (v) pemasaran belum berkembang karena produk industri pengolahan pertanian belum memenuhi persyaratan pasar, khususnya pasar internasional; (vi) belum adanya kebijakan riil yang mendorong berkembangnya industri pertanian di dalam negeri.

Dengan memahami deskripsi pemberdayaan dan pengembangan kelembagaan perdesaan, diharapkan menjadi landasan pemikiran dalam mengkaji pengembangan industri pengolahan pertanian di perdesaan, dalam rangka terciptanya struktur perekonomian yang seimbang di perdesaan (Elizabeth, 2014). Hubungan interdependensi atau kemitraan kelembagaan yang terbentuk mencirikan interaksi yang sangat asimetris, sehingga dinilai tidak 
menguntungkan bagi perbaikan kualitas ketenagakerjaan (SDM) petani, yang mencerminkan sentralistik kebijakan perancang pembangunan (top down), centrally planned economies (Kozminski, 1990; dalam: Elizabeth, 2014; 2016; 2018a) dan monolitik, sehingga terkesan sulit berkembang dan tidak mengakar pada adat, kebudayaan dan local knowledge masyarakat setempat. Untuk memperbaiki kondisi tersebut diperlukan pengembangan dan pemberdayaan kelembagaan tradisional, yang dimulai dari masyarakatnya agar menjadi esensial untuk mencapai kesinergisan optimum dalam aktivitasnya di tingkat lokal; membantu peningkatan ke arah industrialisasi; dan memudahkan petani mengembangkan sistem kelembagaan industri pengolahan berbasis produk pertanian (Wijaya, 2011; 2013; Elizabeth, 2018a).

Kebijakan pembangunan dan pengembangan industri pengolahan pertanian di perdesaan terutama untuk mendorong terciptanya keseimbangan struktur perekonomian. Pengembangan industri pengolahan pertanian di perdesaan dimaksudkan berperan dalam penciptaan nilai tambah (utility), penyerapan dan produktivitas kelembagaan seperti tenaga kerja dan pasar (Elizabeth, 2017a). Dalam mewujudkan struktur perekonomian yang seimbang, nilai tambah yang diperoleh tidak hanya dari sisi finansial dan penarik pembangunan sektor pertanian. Pengembangan industri pengolahan pertanian di perdesaan perlu disertai oleh program yang langsung menuju ke sasaran (rumah tangga petani sebagai subjek), dimana agroindustriral development dikombinasikan dengan rural development sehingga menjadi satu program pembangunan perdesaan komprehensif, yaitu: "ruralagroindustrial development". Dengan demikian, berbagai sasaran dalam pengembangan industri pengolahan pertanian, seperti: terciptanya nilai tambah dan lapangan kerja, terserapnya sejumlah tenaga kerja, peningkatan pengetahuan dan ketrampilan SDM dalam teknologi pengolahan, terbukanya peluang usaha pengolahan produk berbahan baku pertanian, meningkatnya akses terhadap informasi di luar desa, mampu memotori industrialisasi pedesaan, meningkatnya pertumbuhan ekonomi, peningkatan pembagian dan penyebaran pendapatan, peningkatan penerimaan devisa, serta perbaikan kelembagaan pasar sehingga mampu meraih dan memperluas jangkauan 
pemasaran (Elizabeth, 2011; Wijaya, 2013; 2014 dalam Putra, 2014).

\section{KESIMPULAN DAN IMPLIKASI KEBIJAKAN}

- Pengembangan teknologi produk olahan yang inovatif merupakan satu faktor penunjang peningkatan agroindustri perdesaan, terkait pemberdayaan dan pengembangan kelembagaan pertanian perdesaan.

- Pengembangan industri di sekitar bahan baku, diprediksi sebagai salah satu solusi efisiensi, efektifitas, kontiniutas dan kesinambungan bahan baku, tenaga kerja dan permodalan (pembiayaan).

- Dayasaing produk olahan Indonesia masih lemah, karena selama ini hanya mengandalkan keunggulan komparatif dengan kelimpahan sumberdaya alam dan tenaga kerja tak terdidik (factordriven), sehingga produk yang dihasilkan didominasi oleh produk primer atau bersifat natural resourcesbased dan unskilled-labor intensive.

- Implementasi teknologi spesifik lokasi yang inovatif memiliki kredibilitas, bisa memberi inspirasi semangat kerja untuk maju, perlu dipertimbangkan dan dijadikan dasar perancangan pengembangan agroindustri perdesaan.
- Selain dari sisi finansial, perolehan nilai tambah (utility) agroindustri olahan perdesaan juga dapat meningkatkan penyerapan tenaga kerja, meningkatlan pengetahuan dan ketrampilan SDM mengimplementasi inovasi teknologi pengolahan, terbukanya peluang usaha, meningkatnya akses terhadap informasi di luar desa, dan meningkatnya pertumbuhan ekonomi.

- Program pengembangan teknologi dan investasi melalui pengembangan agroindustri pedesaan mampu menjadi "mesin penggerak" kemajuan ekonomi tangguh, jika sistem kelembagaannya berfungsi sejalan pelaksanaan program pembangunan.

- Kebijakan pemerintah umumnya bisa investasi fisik dan permodalan lebih bermanfaat bila identik dengan pengembangan kelembagaan perdesaan dengan perkembangan pertanian, diharapkan mampu mengakomodasi pengembangan agroindustri.

- Sebagai penghela pembangunan pertanian, agroindustri diharapkan mampu menciptakan berbagai produk pertanian dan olahannya, agroindustriral development dikombinasikan rural development 
menjadi satu program pembangunan perdesaan komprehensif, yaitu: "rural-agroindustrial development", mampu memotori industrialisasi perdesaan, serta mampu menciptakan lapangan kerja dan pendapatan di perdesaan.

\section{DAFTAR PUSTAKA}

Badan Litbang Pertanian Deptan. 2015. Prospek dan Arah Pengembangan Agribisnis. Balitbang Deptan. Jakarta.

Elizabeth, R. 2011. Strategi Pencapaian Diversifikasi Dan Kemandirian Pangan Dalam Rangka Mewujudkan Ketahanan Pangan: Antara Harapan Dan Kenyataan. Buku IPTEK. Pusat Penelitian dan Pengembangan Tanaman Pangan. Badan Litbang Pertanian. Kementerian Pertanian.

Elizabeth, R. 2016. Pemberdayaan Petani Dalam Pengelolaan Tanaman Dan Ternak Guna Meningkatkan Kesejahteraan Petani. Prosiding Seminar Nasional Agustus 2016. BPTP Sulawesi Utara. Manado. Badan Litbang Pertanian. Sekretaris Jenderal Pertanian. Kementerian Pertanian.

Elizabeth. R. 2014. Mewujudkan Kemandirian Dan Ketahanan Pangan Melalui Revitalisasi Dan Pengembangan Infrastruktur Pertanian. Konferensi Nasional XVII dan Kongres XVI PERHEPI. IPB International Convention Center (IICC). Bogor. 28-29 Agustus 2014.

Elizabeth. R. 2017. Revitalisasi Industri Produk Olahan Dan Pemberdayaan Lembaga Kemitraan Mendukung Peningkatan Pemasaran, Daya
Saing Dan Pensejahteraan Petani Pisang. Journal of Agricultural Scienties. UNES. (Universitas Ekasakti). Padang Sumatera Barat. Volume 2. Issue 1. June 2017. ISSN Cetak: 2528-5556. ISSN Online: 2528-6226.

Elizabeth. R. 2017a. Akselerasi Pemberdayaan Dan Peningkatan Kompetensi Dalam Sistem Produksi Untuk Mengatasi Permasalahan Ekonomi Di Indonesia. Volume 2. Issue 1. June 2017. ISSN Cetak: 2528-5556. ISSN Online: 2528-6226.

Elizabeth. 2018. Akselerasi Agroindustri Dan Nilai Tambah: Faktor Pendukung Pencapaian Dayasaing Produk Dan Percepatan Pembangunan Pertanian Di Indonesia. OJS. Online Jurnal System. UNES (Univ. Ekasakti). Padang. Sumatera Barat.

Elizabeth. 2018a. Akselerasi Pencapaian Dayasaing Produk Agroindustri Melalui Revitalisasi

Berkesinambungan Implementasi Pemberdayaan Kelembagaan Pertanian. Buku. Puslitbangtan. Kementerian Pertanian. Jakarta.

Elizabeth, R. 2019. Revitalisasi Implementasi Pemberdayaan Kelembagaan Pertanian Berkesinambungan Mendukung Pencapaian Dayasaing Produk Olahan. Volume 2. Issue 2. June 2019 OJS. Online Jurnal System. UNES (Univ. Ekasakti). Padang. Sumatera Barat.

Fauzi Aziz. 2014. Hilirisasi Cermin Politik Industri. Bisnis Indonesia. http://www.neraca.co.id/bisnisindonesia. (6-6-2021).

Hadi P. 2014. Reformasi Kebijakan Penciptaan Nilai Tambah Produk Pertanian Indonesia. Reformasi Kebijakan Menuju Trasformasi 
Pembangunan Pertanian. Haryono (editor). Badan Litbang Pertanian.

Kaniasari, N. 2012. Meningkatkan Nilai Tambah dan Daya Saing Produk Pertanian.

Kementerian Keuangan Republik Indonesia. 2014. Laporan: Kajian Nilai Tambah Produk Pertanian. Laporan.

Kementerian Koodinator Bidang

Perekonomian. 2016. Outlook Ekonomi Indonesia 2017:

Melanjutkan Reformasi: Menjaga Ketahanan dan Memacu Pertumbuhan Ekonomi. Jakarta, 10 November 2016.

Kusumawardani MH. 2012. Membuat Rantai Nilai Lebih Berpihak Pada Kaum Miskin: Buku Pegangan Bagi Praktisi Analisis Rantai Nilai. Australian Goverment(AU): Aciar.

Marimin, dan Maghfiroh N. 2011. Aplikasi Teknik Pengambilan Keputusan dalam Manajemen Rantai Pasok. IPB Press.

MSN. 2017. Kemtan Genjot Ekspor Beras Organik. https://www.msn.com/id$\mathrm{id} /$ ekonomi/ekonomidanbisnis/kemt an-genjot-ekspor-beras-organik/arAAo1SLh (3 Juni 2021).

Putra IKTE, IPG Sukaatmadja, N Ny K Yasa. 2016. Perilaku Konsumen Mengkonsumsi Beras Organik Dikota Denpasar Berdasar Theory Of Planned Behavior. E-Jurnal Ekonomi dan Bisnis Univ. Udayana 5.8 (2016):2609-2638. ISSN:23373067
Rachmat, M. R. Elizabeth. Supadi. H. Supriyadi. P. U. Hadi. S. Nuryanti. 2012. Studi Kebutuhan Pengembangan Produk Olahan Pertanian Dalam Rangka Liberalisasi Perdagangan. LHP. PSEKP. Bogor. Badan Litbang Pertanian. Kementerian Pertanian. Jakarta.

Ridwan R. Model Penggilingan Padi Terpadu Untuk Meningkatkan Nilai Tambah. Buletin Teknologi Pascananen Pertanian Vol 8 (2), 2012.

Susilawati S H,. H P Saliem. E. Ariningsih. R. Elizabeth. C R Addawiyah. 2018. Strategi Antisipatif Pengelolaan Surplus Produksi Padi Dan Jagung. LHP. PSEKP. Sek Jen. Kementan.

Uphoff, N. 1992. Local Institution and Participation for Sustainable Development. IIED. London.

Wijaya, Tony. 2014. Nilai dan Pengetahuan sebagai Prediktor Intensi Membeli Makanan Organik. Jurnal Manajemen dan Kewirausahaan, 16:69-82.

Wijaya, Tony. 2013. Anteseden Perilaku beli Produk Ramah Lingkungan : Studi Perilaku Konsumen Makanan Organik. Jurnal Ekonomi dan Bisnis, 7(3):149-161.

Wijaya, Tony dan Hidayat, A. 2011. Model intense pembelian makanan organik, Call for Paper Update Ekonomi, Akuntansi dan Bisnis Indo Indonesia, Proceeding Fakultas Ekonomi UII,Yogyakarta. 